\title{
European Security and Private Military Companies: The Prospects for Privatized "Battlegroups"
}

\author{
James $K$ Wither *
}

\section{Introduction}

"Mercenary" remains a pejorative term. It is associated with the hired killers implicated in coup attempts in Africa in the 1960s and 1970s, and more recently associated with human rights abuses in post-Cold War conflicts in Eurasia and the Balkans. However, until the nineteenth century a large part of the armed forces of most European nations was supplied by the private sector. It was normal for professional soldiers-especially those with technical expertise, such as artillerymen or siege engineers - to offer their services on the open market. Often contractors organized soldiers into formed units on behalf of paying clients, notably the condottieri that held a monopoly on providing military services to the city-states of fifteenth-century Italy. Later, formed bodies of mercenaries were hired by the emerging nation-states of Western Europe and integrated into their armies. Units of Swiss, Scots, and Irish soldiers served in the armies of France. Great Britain hired nearly 30,000 German mercenaries to help fight the rebellious American colonists. Commercial contractors were also required to equip, feed, and sustain troops in the field, carrying out many tasks that would later be performed by uniformed logisticians in the large standing armies of the twentieth century. But, just as mercenaries supplanted unreliable feudal levees towards the end of the Middle Ages, they began to fall from favor as the scale of warfare increased and mass citizen armies emerged during the French revolutionary wars. For the last two centuries, a state monopoly on armed violence has been an accepted feature of national sovereignty.

In the early twenty-first century, political, technological, and societal developments have again combined to change the predominant character of armed conflict. A complex and unpredictable security environment has replaced the threat of large-scale interstate war. Compulsory military service and large standing armies have become anachronisms, while the bonds of national sentiment and identification that helped to sustain these forces are in decline. To the extent that emerging security threats require a military response, the need is for rapidly deployable, expeditionary forces capable of conducting operations in a wide variety of environments. However, most member states of the European Union (EU) appear reluctant to reform and resource their armed forces to provide these capabilities. Given these conditions, this exploratory paper examines whether the states of Europe could once again turn to the modern-day equivalent of the condottieri, private military companies (PMCs), to supplement or even substitute for their national military forces in an expeditionary role. A PMC is defined as an enterprise organized on corporate lines, which is formally contracted to provide

James Wither is Professor of National Security Studies, George C. Marshall European Center for Security Studies. 
military services to its clients. ${ }^{1}$ These services can be restricted to training and support functions, but may also include combat activities. The focus of this essay is on what P.W. Singer has classified as "military provider firms," those that supply direct combat services. $^{2}$

\section{The Military Challenge for Post-Modern Europe}

The Europe of nineteenth-century imperialism and twentieth-century total war is no more. The collapse of the Soviet Union and the success of the European integration project have transformed international relations within the continent. European states of the early twenty-first century show no inclination to make war on each other or conquer territory. The commitment to the peaceful resolution of disputes, cooperation through common institutions, and growing interdependence and transparency have largely replaced inter-state relationships based on narrow definitions of sovereignty, national interests, and the balance of power. Consequently, the British diplomat Robert Cooper has described the EU as a "post-modern system." He distinguishes European states from countries elsewhere in the world, where traditional concepts of national interest and military power still dominate security thinking, and from so-called "failed states," where national institutions and authority have largely collapsed. ${ }^{3}$

EU states favor using diplomatic and economic tools to address the underlying causes of conflict outside Europe, and place their faith in multilateral approaches based on international institutions and the rule of law to tackle emerging security challenges. Nevertheless, the EU's strategy paper of December 2003 identifies specific threats to European security, namely the proliferation of weapons of mass destruction, terrorism, and state failure. While the drafters recognize that "none of the new threats to security is purely military, nor can any be tackled by purely military means," military capabilities are acknowledged as necessary in efforts to counter terrorism, restore order in failed states, and assist with post-conflict reconstruction. ${ }^{4}$ The strategy paper also stresses the need to "develop a strategic culture that fosters early, rapid and when necessary, robust intervention. "Robust intervention" must include the option to apply military force outside of Europe if necessary to combat terrorism, prevent humanitarian tragedies, or evacuate EU citizens caught up in civil wars.

Unfortunately, the rhetoric of European security ambitions is not matched by the military reality. The European Institute for Security Studies has concluded that, "The

1 A comprehensive discussion of the distinction between mercenaries, private armies, private security companies, and PMCs is provided by Dr. Kevin A. O'Brien in "PMCs, Myths and Mercenaries: The Debate on Private Military Companies," RUSI Journal 145:1 (February 2000).

2 Peter W. Singer, Corporate Warriors: The Rise of the Privatized Military Industry (Ithaca, NY: Cornell University Press, 2003), 92-95.

3 Robert Cooper, "The New Liberal Imperialism," The Observer, 7 April 2002.

4 European Security Strategy, A Secure Europe in a Better World, Brussels, 12 December 2003,7 .

5 Ibid., 11. 
Union cannot deploy land forces quickly and cannot sustain them, due to the shortage of committed, deployable, combat ready forces." The "Headline Goal 2010," endorsed by the European Council in June 2004, is an attempt to address these shortfalls. ${ }^{7}$ Under the Headline Goal, the EU will respond to crises throughout the worldincluding humanitarian missions, rescue tasks, peacekeeping, and disarmament operations - with forces ready to implement their mission within ten days of a decision to deploy. A key feature of the Headline Goal is the proposal to create up to thirteen selfsustaining, rapidly deployable battalion-sized combined arms "battle groups," with a forced entry capability and the capacity to operate in a wide variety of combat environments in response to requests from the United Nations (UN). France, the United Kingdom (U.K.), Italy, and Spain have indicated that they will each supply a battle group. However, concerns have also been expressed about "straining the budgets and capabilities of the smaller member states," providing EU peacekeeping support to the UN, the U.K.'s Director General of International Security Policy acknowledged that the creation of these battle groups would be "extremely challenging" for most EU member states.

\section{Europe's Military Weakness}

During the Cold War, European security depended on the guarantee of United States (U.S.) support through the medium of the NATO alliance. But since 1990, U.S. and European threat perception and strategic thinking have often diverged. Despite NATO's program of military transformation, the differences within the transatlantic partnership suggest that it might be hard to arrive at the necessary political consensus to deploy the alliance's new flagship NATO Response Force (NRF) in a timely and effective manner. NATO has even struggled to provide adequate helicopter support to its International Stabilization and Assistance Force (ISAF) operation in Afghanistan.

The EU'S attempt to develop its own distinct intervention capability recognizes the eventuality that the Union may have to address security interests beyond its borders without direct support from the U.S., even if NATO resources are made available. In fact, EU-sponsored peacekeeping and enforcement operations have already begun, albeit on a modest scale. The EU may have failed to meet its much-trumpeted original Headline Goal force targets by 2003 as intended, but in the same year the Union assumed responsibility for peacekeeping in Macedonia and policing in Bosnia, as well as

6 Institute for Security Studies, European Defence: A Proposal for a White Paper (Paris: European Union, 2004), 100. Available at: http://www.iss-eu.org/chaillot/wp2004.pdf.

7 Headline Goal 2010, EU General Affairs and External Relations Council, 17 May 2004. Available at: http://ue.eu.int/uedocs/cmsUpload/2010\%20Headline\%20Goal.pdf.

8 John Smith, "The Development of Response Forces in NATO and the EU and the Evolving NATO-EU Relationship," NATO Parliamentary Assembly, Committee Reports, 2004 Annual Session (159 DSFC $04 \mathrm{E}$ ), paragraph 20. Available at: www.nato-pa.int/default.asp?TAB= 488.

9 Sarah Beaver, "The EU, a New Partner for the UN in Peacekeeping," RUSI Journal 149:4 (August 2004): 17. 
mounting Operation Artemis, a French-led humanitarian relief intervention in the Congo. ${ }^{10}$ All told, between 50,000 and 60,000 troops from EU countries were deployed outside of the NATO and EU area, in more than twenty countries. ${ }^{11}$

The extent of these deployments appears impressive, but the ability of many EU armed forces to undertake military operations except in benign peacekeeping environments is doubtful. Operation Allied Force in Kosovo in 1999 revealed significant gaps in European military capabilities, and progress to address these shortfalls has been slow and inconsistent despite a common commitment to the European Capabilities Action Plan in 2001. A 2003 report by the Bonn International Center for Conversion highlighted a long list of deficiencies, one that was little changed from those identified in 1999, including critical force multipliers such as strategic airlift, electronic warfare, secure communications networks, intelligence assets, and special forces. ${ }^{12}$ According to Professor de Wijk of the Clingendael Center for Strategic Studies, only 10 percent of the EU's military forces are suitable for deployment on overseas combat missions, although member states have approximately 1.7 million men and women under arms. ${ }^{13}$ Currently, only the British and French have an independent capability to mount expeditionary operations outside of the European area, although their capacity to act without U.S. support is limited. Nevertheless, the EU has taken over from NATO in Bosnia, and the possibility of future deployments to Moldova and the Sudan has been discussed. ${ }^{14}$ If the operational tempo increases, those few states that possess effective armed forces are likely to balk at continuing to shoulder a disproportionate share of the military burden, with its attendant political risks and inevitable casualties.

Western militaries have been described as "increasingly unpatriotic in motivation, civilian in ethos and constabulary in purpose." "Such a viewpoint would be anathema to many professional officers and soldiers in Western armed forces, but the militaries of EU states are arguably a reflection of a general public which, if not manifestly pacifist, appears increasingly reluctant to support the use of force as an instrument of policy in international relations. ${ }^{16}$ Few governments are willing to pay the financial and

10 The Headline Goals agreed at the Helsinki Conference in 1999 aimed to establish a Rapid Reaction Force of 60,000 by 2003 that could be deployed within sixty days with the necessary support to fulfill the full range of Petersberg military tasks.

11 Bastain Giegerich and William Wallace, "Not Such a Soft Power: the External Deployment of European Forces," Survival 46:2 (Summer 2004): 164.

12 Jocelyn Mawdsley and Gerrard Quille, "Equipping the Rapid Reaction Force: Options for and Constraints on a European Defence Equipment Strategy," Bonn International Center for Conversion, Paper 33 (Bonn: BICC, 2003), 48-67.

13 Rob de Wijk, "European Military Reform for a Global Partnership," Washington Quarterly 27:1 (1 December 2003): 197

14 Smith, "Development of Response Forces," paragraph 42.

15 Frédéric Mérand, "Dying for the Union?: Military Officers and the Creation of a European Defence Force," European Societies 5:3 (2003): 259.

16 The German Marshall Fund of the United States, Transatlantic Trends 2003, 13-15. The statistics suggest significant differences between European and American public opinion on the use of force. Available at: http://www.transatlantictrends.org/. 
political price of diverting resources from domestic health, education, and social priorities in order to enhance their military capabilities during an era of unprecedented peace in Europe. Thus the bulk of the EU's soldiers may be ill prepared for the kind of high-intensity combat that might be necessary during expeditionary operations. Nor will they necessarily be effective in a gendarmerie role as peacekeepers. The British experience in Iraq has indicated that soldiers must be ready to handle humanitarian tasks, stabilization functions, and combat operations concurrently. ${ }^{17}$ It is doubtful if many states can be relied upon to field troops with the appropriate training, equipment, flexibility, or even resolve to soldier effectively under such exacting conditions. ${ }^{18}$

The response of some soldiers from EU states to the more demanding peacekeeping tasks on recent operations has already raised concerns about their combat readiness, although it is only fair to note that many peacekeeping contingents have had to operate within very restrictive rules of engagement imposed by governments anxious to avoid casualties that could undermine domestic support for their policies. Dutch troops were accused of cowardice following their failure to protect the Muslim population of Srebrenica from Serbian aggression and massacre in 1995, a disaster that caused much disquiet and debate in the Netherlands. ${ }^{19}$ The International Crisis Group report on the unrest in Kosovo in March 2004 highlighted the failure of Italian, French, and German Kosovo Force (KFOR) units to confront Albanian mobs intent on attacking the Serbian minority. ${ }^{20}$ Police officers who vainly attempted to stop the rioting talked of a "Srebrenica syndrome," accusing KFOR soldiers of running away instead of standing their ground in the face of violence. ${ }^{21}$ Spanish troops came in for similar criticism during the upsurge in violence in Iraq in spring 2004. A combat team from the elite "Plus Ultra"

17 British Ministry of Defense, Operations in Iraq: Lessons for the Future (London: DCCS Pubs, December 2003), Chapter 3, paragraph 3.4. Available at: www.mod.uk/publications/ iraq futurelessons/chap3.htm.

18 See, for example, a damning report on the Belgian military by Philip Shishkin, "Growing Soft: How the Armies of Europe Let Their Guard Down - Guaranteed Jobs for Soldiers Leave Little Room to Buy Equipment or Even Train-Battle of the Belgian Bands," Wall Street Journal, 13 February 2003, A1. A letter criticizing the article from Andre Flahaut, the Belgian Minister of Defense, published on 26 February 2003, did little to refute the author's arguments.

19 For a summary of the controversy in Holland over the events at Srebrenica see Abi Daruvalla, "Anatomy of a Massacre," Time, 21 April 2002. Available at: www.time.com/ time/europe/magazine/article/0,13005,901020429-232505,00.html.

20 International Crisis Group, Collapse in Kosovo, ICG Europe Report No. 15 (Pristina/Belgrade/Brussels: ICG Europe, 22 April 2004), 19-24.

21 Ibid., 22. NATO countries have worked hard to eliminate many of the national caveats that handicapped the performance of peacekeepers during the rioting in Kosovo in March 2004. See Daniel Dombey, "International Policy on Kosovo Shifts After Criticism," Financial Times, 10 September 2004. 
brigade refused to deploy to assist Latin American contingents under attack from insurgents in Najaf until after the fighting was over. ${ }^{22}$

The armed forces of the new EU member states can currently contribute little to expeditionary operations. Essentially, they are still organized and equipped for general war, not limited intervention. Poland is making a serious effort to modernize, but as the preparations for deployment to Iraq revealed, its armed forces will need substantial investment to develop an effective expeditionary capability. ${ }^{23}$ In other countries, such as Hungary and Slovakia, there is a lingering reluctance to shift from a military emphasis on territorial defense, mainly because of the political and economic costs of restructuring and downsizing armed forces. Many states still retain conscription policies, but conscript soldiers can normally only be used for collective defense or in the most undemanding peacekeeping environments. Forces with a Cold War-era organization and mindset will be of little assistance to the EU as it seeks to develop an effective intervention capability.

\section{Back to the Future: The Re-emergence of Private Military Companies}

While Europe's state militaries struggle with reform and restructuring, the heirs of the condottieri are thriving. Globally, the private sector offers the full range of military services from combat infantrymen to strategic consultancy. Between 1994 and 2002, the Pentagon entered into more than three thousand contracts with PMCs. ${ }^{24}$ The extent of privatization is illustrated by statistics from the two wars against Iraq. In the campaign of 2003, the ratio of civilian contractors to military personnel was $1: 10$, compared to an estimated 1:50 at the time of the Gulf War in $1991 .^{25}$ A two-year research project by the International Consortium of Investigative Journalists completed in 2002 identified around 90 PMCs, which had collectively operated in 110 countries throughout the world. ${ }^{26}$ The war in Iraq and its aftermath have resulted in a huge expansion in private sector military activity. The revenues of British PMCs alone are estimated to have risen from $\$ 320$ million before the war to over $\$ 1.6$ billion by March $2004 .^{27}$

The growth of PMCs has been driven by a number of factors, most of them unique to the post-Cold War era. Since the early 1990s there has been a significant reduction

22 Interview by the author with a senior U.S. Marine Corps officer from the Marine Expeditionary Force on 1 December 2004. He claims Spanish commanders were unprepared for combat and more concerned with their soldiers" "creature comforts" than with the tactical situation.

Andrew A. Michta, "Central Europe and the Baltic Littoral in NATO," Foreign Policy Research Institute (Summer 2004): 415.

24 P.W. Singer, "Have Guns, Will Travel," New York Times, 21 July 2003.

25 David Isenberg, "A Fistful of Contractors: The Case for a Pragmatic Assessment of Private Military Companies in Iraq," British American Security Information Council (BASIC), Research Report 2004-4 (September 2004), 7. Available at: www.basicint.org/pubs/Research/ 2004PMC.htm.

26 Laura Peterson, "Privatizing Combat, the New World Order," The Center for Public Integrity, 28 October 2002, 2. Available at: http://www.publicintegrity.org/bow/report.

27 The Economist, 27 March 2004, 37. 
in the size of armed forces around the world. The U.S. military, for example, is 35 percent smaller than at the time of the Gulf War. During the same period, North American and European soldiers have deployed on more military operations than they had during all forty years of the Cold War. These operations have covered the full spectrum of conflict, from peace support to high-intensity combat, demanding a range of military skills and experience beyond the capabilities of many states. Private contractors have expanded to meet the skills gap and to fill the shortages caused by the reduction in the number of military personnel. This expansion has been assisted by the availability of individuals with appropriate expertise who have found themselves without work through the downsizing of state militaries. The complexity of modern military hardware has also fuelled the growth of a small army of civilian maintenance specialists. The U.K. employed around 1500 civilian contractors during the Iraq campaign in 2003, mainly to provide equipment and technical support, not least because British soldiers lacked the specialized skills to service the more sophisticated equipment in the field. ${ }^{28}$ As equipment maintenance is increasingly carried out by the original manufacturer, contractor support on operations has become vital for advanced Western militaries. $^{29}$

The broader political vogue for privatization has also played an important role in the growth of military enterprises. It has become an article of faith that the public sector should be exposed to the rigors of the market to benefit from what are perceived to be cost effective commercial financial and management practices. Although the benefits of outsourcing public sector activities are sometimes disputed, defense ministries have not been exempt from this trend, and the private sector now provides many service-support functions such as cleaning, catering, transport, and training services, even on operations. ${ }^{30}$ In Kosovo, the U.S. firm Brown \& Root Services (BRS) supplied U.S. forces with 100 percent of their food, vehicle maintenance, and hazardous materials handling; 90 percent of their water; and 80 percent of their fuel provision. ${ }^{31}$ In Europe, the U.K. has led the trend towards outsourcing since the Thatcher government's reforms in the 1980s. Various initiatives, such as "Competing for Quality" and "Private Finance Initiatives," have resulted in the complete or partial privatization of a wide range of military support functions, including potentially mission-critical tasks such as air-to-air refueling. The U.K.'s concept of "Sponsored Reserves" already arguably

28 British Ministry of Defense, Operations in Iraq: Lessons for the Future (London: DGCC Publications, December 2003), Chapter 8, paragraph 8.23. Available at: www.mod.uk/ publications/iraq_futurelessons/chap8.htm.

29 For examples of the U.S. military's dependence on contract technicians during the war in Iraq in 2003, see: Isenberg, "Fistful of Contractors," 21.

30 A Pentagon report from 1995 estimated savings of up to \$6 billion annually by 2002 if all military support functions were contracted out to the private sector. See Peterson, "Privatizing Combat," 3.

31 Singer, Corporate Warriors, 145; see also Table 9.1, 144. 
blurs the distinction between the armed forces and the civilian employees of PMCs in the field. ${ }^{32}$

Most controversially, the employment of PMCs has allowed military assistance to be supplied in situations where it might have been politically unpalatable to use the regular armed forces. ${ }^{33}$ U.S.-based private firms have carried out clandestine operations proscribed by Congress or unpopular with the American public, most notably in Colombia. Federal law prevents U.S. troops from participating in the war against the Revolutionary Armed Forces of Columbia (FARC) guerrillas, but PMCs hired by the government have been used to train the Colombian army and combat the drug trade on which FARC depends for funding.

PMCs already undertake a range of peacekeeping tasks for the UN and other nongovernmental organizations (NGOs), including the provision of security for humanitarian assistance, the construction and operation of medical facilities, and de-mining services. As noted above, civilian contractors provide critical combat support and combat service support to Western militaries on operations. Yet the growth of the private military industry is far from universally applauded, and no European state has yet employed a PMC in a direct combat role. The very idea of military provider firms operating at the cutting edge of EU expeditionary forces would currently be an unthinkable and even distasteful prospect for many policy makers. Nonetheless, at present armed forces face rapid and continuing changes in the structure, roles, and delivery of military force in response to the emergence of novel security challenges and technical transformation. The privatization of military services is part of a continuing change process that began at the end of the Cold War and seems set to continue, as the breakup of the state monopoly on military services deviates from the norm of the last two centuries, when armed forces were exclusively financed and controlled by state governments.

PMCs have already taken over many functions that were until recently the exclusive preserve of uniformed personnel. Formed units from military provider companies have also demonstrated the private sector's ability to intervene effectively in the kind of intrastate conflicts in Africa that the EU's battle groups are intended to tackle. Since the mid 1990s, many officials and commentators have contemplated moving toward "privatized peacekeeping" because of the persistent failings of the national military contingents deployed on UN missions. P. W. Singer of the Brookings Institute has de-

32 Under the Reserve Forces Act 1996, PMCs can provide support services in conflict situations by allowing their employees to become "special members of a reserve force." As reservists, these employees are liable for "call out," subject to service discipline and regulations, and receive appropriate military training. See: www.legislation.hmso.gov.uk/ acts/acts1996/96014--e.htm\#39. See also discussion in Elke Krahmann, "Controlling Private Military Companies: The United Kingdom and Germany," Paper for International Studies Association Annual Convention 2003, Center for European Studies, Harvard University, 89.

33

See, for example, Abraham McLaughlin, "Guns for Hire Thrive in Africa," Christian Science Monitor, 15 March 2004, which covers U.S. contractor activity in Equatorial Guinea. 
scribed the emergence of private firms as heralding "tectonic" changes in the way military capabilities are provided to both states and non-state actors. ${ }^{34}$ American military analyst Steve Metz has also predicted that, "Corporate armies, navies, air forces, and intelligence services may be major actors in twenty-first century armed conflict." Other commentators have even questioned whether the motivation and morality of soldiers in modern professional armed forces can really be distinguished from the socalled "mercenaries" employed by PMCs. ${ }^{36}$

\section{Privatized Peacekeeping and Enforcement: PMCs in Direct Combat Roles}

As the services of PMCs became increasingly critical to the success of peacekeeping missions in the 1990s, it was inevitable that employees from these companies found themselves placed in "harms way." Contractors from Defence Systems Limited (DSL), a PMC based in the U.K., provided transport, maintenance, communications, and engineering services for the United Nations Protection Force (UNPROFOR) in Bosnia. But these activities involved DSL employees driving armored personnel carriers on peacekeeping operations and sometimes delivering supplies to bases under small arms and artillery fire. ${ }^{37}$ In an unprecedented venture for a PMC contracted by a Western government, the United States hired the Virginia based DynCorp to supply ceasefire monitors for Kosovo in 1998. Although the DynCorp employees were unarmed, they were deployed into a potential combat environment instead of regular soldiers. ${ }^{38}$

As non-linear battlefields and asymmetrical methods of warfare come to characterize more contemporary armed conflicts, the distinction between combatant and noncombatant has become increasingly blurred. Although none of the PMCs in Iraq was hired to take part in combat operations, contractors providing military security services, such as installation protection and convoy escort, were forced into direct combat with insurgents during the eruption of violence in spring 2004. Four employees of Blackwater USA were ambushed, killed, and mutilated while on convoy escort duty in Fallujah. A few days later, eight "commandos" from the same PMC successfully de-

34 Singer, Corporate Warriors, 18.

35 Dr. Steven Metz, Armed Conflict in the 21st Century, The Information Revolution and Post Modern Warfare (Carlisle, PA: Strategic Studies Institute, U.S. Army War College, 2000), 21. Available at: http://www.carlisle.army.mil/ssi/pdffiles/PUB226.pdf.

36 See for example, Brendan O'Neil, "Is it Mercenary to Join for Perks, Not War," Christian Science Monitor, 1 June 2004, 9; and comments by Professor William Douglas of John Hopkins University, quoted in Jim Fisher-Thompson, "Contracting for Peace is Rational Approach," U.S. Department of State, International Information Programs, 28 November 2003. Available at: http://usinfo.state.gov.

House of Commons, Select Committee on Foreign Affairs Minutes of Evidence, Appendix 6, "Memorandum from Armor Group Services Limited: A Contractor's View," 23 July 2002, paragraphs $73-80$.

38 Jonathan Steele, "US Gives Kosovo Monitoring Job to Mercenaries," Guardian Media Group plc., 1998; available at: http://taf.ilim.ru/public/kosovo1.html. 
fended the U.S. headquarters in Najaf against an attack by hundreds of Iraqi militia. During the operation, helicopters manned by Blackwater employees even ferried in fresh ammunition and evacuated the wounded. ${ }^{39}$ As major security firms recruit former members of the special forces and other elite combat units, it is hardly surprising that these employees and personnel from other security firms such as Control Risk Group, Triple Canopy, and Hart Group Ltd. acquitted themselves well under fire. ${ }^{40}$ In some cases, private contractors proved to be more professional and effective than coalition troops. Triple Canopy's operatives fought for three days to protect civilian members of the Coalition Provisional Authority (CPA) at a facility in Kut after Ukrainian soldiers apparently retreated from their positions. ${ }^{41}$

While PMCs in Iraq have demonstrated their competence to fight limited defensive battles in low-intensity conflicts, elsewhere private sector forces have already taken a leading role in offensive military operations in theatres of war as far apart as Macedonia, Colombia, and sub-Saharan Africa. It was the successful interventions by the South African PMC Executive Outcomes (EO) in the mid 1990s against rebels in Angola and Sierra Leone that brought the issue of the employment of PMCs in direct combat to the forefront of discussion. EO's operation in Sierra Leone in 1995, in particular, was a classic example of what a small force of highly skilled, professional soldiers from a military provider firm can achieve against the more numerous but poorly trained irregular fighters that make up the bulk of combatants in conflicts in the developing world. The company employed a battalion-sized force of infantry, supported by combat helicopters, light artillery, and some armored vehicles, which completely defeated rebel forces of the Revolutionary United Front (RUF) in a few weeks. ${ }^{42}$ EO's success contrasted sharply with the United Nations Mission in Sierra Leone's (UNAMSIL) costly and ineffective operation, and launched much debate about the possibilities of privatized peacekeeping and enforcement. ${ }^{43}$ An Adelphi Paper from 1998 argued for governments and international institutions to begin a "constructive en-

39 See Dana Priest, "Private Guards Repel Attack on U.S. Headquarters," Washington Post, 6 April 2004; and David Barstow, "Security Firm Says Its Workers Were Lured Into Iraqi Ambush," New York Times, 9 April 2004.

40 Dana Priest and Mary Pat Flaherty, "Under Fire, Security Firms Form an Alliance," Washington Post, 8 April 2004; and Brendan O’Neill, “A New Kind of Private War,” spikedpolitics, 16 April 2004; available at: www.spiked-online.com/Articles/0000000ca4dd.htm.

41 Isenberg, "Fistful of Contractors," 31. Military provider firms employed in Africa in the 1990s also proved reliable, completing their contractual obligations despite significant casualties. See Christopher Spearin, "Private Security Companies and Humanitarians: A Corporate Solution to Securing Humanitarian Spaces?” International Peacekeeping 8:1 (Spring 2003): 28.

42 For accounts of EO's operations in Sierra Leone and Angola, see: Elizabeth Rubin, "An Army of One's Own," Harper's Magazine (February 1997): 44-55; Eugene B. Smith "The New Condottieri and US Policy: The Privatization of Conflict and Its Implications," $\mathrm{Pa}$ rameters 32:4 (Winter 2002-2003): 104-19; and Singer, Corporate Warriors, 112-17.

43 See, for example, Jonah Schulhofer-Wohl, "Should We Privatize the Peacekeeping," Washington Post, 12 May 2000, A47. 
gagement" with military companies that might allow them to supplement international and regional peacekeeping activities. ${ }^{44}$ PMCs themselves also appeared anxious to "legitimize" their business activities. Doug Brooks, president of the International Peace Operations Association (IPOA), a lobbying group for companies providing military security, argued strongly that PMCs could supply the "sharp, intensive use of force when necessary to end conflicts quickly" and add much needed "teeth" to peace operations by acting as "force multipliers" for otherwise mediocre local military forces. ${ }^{45}$

\section{Military Provider Companies in Support of EU Expeditionary Forces}

Recent conflicts have illustrated that a small unit of well trained and equipped, highly motivated soldiers can wield tremendous firepower and have a military impact out of all proportion to their numbers. Although even the largest PMC is unlikely to be able to field more than around 500 troops, this should prove sufficient for a limited intervention role with support from EU or NATO combat and logistic assets. In a hypothetical EU operation, a PMC could be hired to intervene rapidly in a deteriorating security situation, defeat local opposition, and stabilize a conflict long enough to allow peacekeepers from member states or the UN to deploy at a more leisurely pace without significant military risks. An intervention operation might involve the creation of a humanitarian safe haven or "corridor." A member of the U.S. National Security Council is reported to have suggested that EO be hired for such an undertaking during the Rwandan refugee crisis in $1996 .{ }^{46}$ In addition to providing units for forced entry operations, a combatant PMC might also provide a rapid reaction force in support of an EU peacekeeping operation. This force could be used to hunt down war criminals, mount combat and hostage rescue missions, and engage in counter-terrorist activities as a supplement or alternative to the employment of overstretched special forces assets from EU member states.

In Sierra Leone, the EO force deployed in the field with integral long-range reconnaissance, surveillance, and signals jamming and intercept capabilities that easily outclassed anything fielded by the RUF. ${ }^{47}$ However, in the future intervention forces could find themselves confronted by opponents with sophisticated technology and expertise as advanced surveillance, communications, and targeting equipment find their way into the arsenals of non-state combatants. Unlike the armed forces of many EU member states, major PMCs have remained abreast of technological developments in the U.S. military in order to continue to service their most lucrative market. Private sector companies are also directly involved in the operation or maintenance of much of the tech-

44 David Shearer, "Private Armies and Military Intervention," Adelphi Paper No. 316, IISS, (February 1998), 76. The author had headed Save the Children Fund programs and served as a senior adviser to the UN Department of Humanitarian Affairs in Liberia and Rwanda Doug Brooks, "Hope for the Hopeless Continent: Mercenaries," Traders: Journal for the Southern African Region 3 (July-October 2000); available at: www.sandline.com/ hotlinks/00_Brooks.pdf.

47 Eugene Smith, “The New Condottieri," 109. 
nology on which evolving network-centric warfare capabilities depend. Therefore, the employment of technologically advanced PMCs conceivably offers EU military planners both a means to bridge some of the gaps identified in the Union's combat and force protection capabilities and remain interoperable with U.S. forces on operations.

On occasion, employees from PMCs have already operated successfully alongside Western armed forces in combat roles. For example, a firm called Express Air was hired to supply pilots to fly Hind attack helicopters in support of British forces during operations in Sierra Leone in $1999 .{ }^{48}$ In a partially privatized peacekeeping scenario, EU expeditionary operations of the future could involve coalitions made up of formed units from both the state and the private sector, a return to the military norm of the early modern period. It is already envisaged that some battle groups will be composed of contingents from a number of different EU states. The incorporation of a PMC, organized and staffed on the lines of advanced Western militaries, into such a formation would arguably be less difficult than the integration of units from some of the smaller, newer, or non-NATO member states.

\section{The Practical Challenges of Employing Military Provider Companies}

There are, of course, significant practical obstacles to the employment of PMCs in a combat role. Currently, only a very limited number of firms are willing or able to provide such services. Military Professional Resources Inc. (MPRI), one of the largest and most prestigious PMCs, claims to have 12,500 veterans on call, but the company eschews a combat role. ${ }^{49}$ A spokesman for ArmorGroup, a major PMC in the training and security fields, has expressed opposition to the very idea of the private sector supplying combat services. ${ }^{50}$ To date, Executive Outcomes and the British firm Sandline are the only companies to have engaged in combat openly, but EO disbanded in 1999 and Sandline ceased trading in April 2004. Both firms were able to draw on South African veterans with a common training, language, and philosophy. In order for a PMC to have the same operational effectiveness with recruits from more diverse origins, substantial, expensive training might be required. Firms providing direct combat services face the additional challenge of maintaining their operatives at a high state of readiness between assignments.

Other companies have the potential to fill the gap left by the demise of EO and Sandline. Gary Jackson, the president of Blackwater, claims to want to have "the largest, most professional private army in the world" ready for peacekeeping duties in any

48 The House of Commons Select Committee on Foreign Affairs Minutes of Evidence, Appendix 8, "Memorandum from MA students of Defence Technology, The Royal Military College of Science, Cranfield University," Chapter 5, The United Kingdom Perspective, 23 July 2002, paragraph 5.4. The pilots were drafted into the Sierra Leone armed forces to provide legitimacy and accountability, and obeyed orders from the commander of British forces in Sierra Leone.

49

See MPRI web site at http://www.mpri.com/site/capabilities.html.

50 House of Commons, "Memorandum from Armor Group Services Limited," paragraph 13. 
country. ${ }^{51}$ Many other established PMCs such as DynCorp and International Charter Incorporated (ICI) could offer combat services, but are not currently in this market. However, the Anglo-American firm Northbridge Services Group has claimed to be able to deploy a fully equipped brigade, including full logistical support, anywhere in the world within three weeks. ${ }^{52}$ The same PMC offered to provide a battalion of peacekeepers for Liberia in 2003 to halt the fighting around Monrovia and arrest the indicted war criminal President Charles Taylor. ${ }^{53}$ The company's web site offers "Operational Support" services including special forces units, air assault capabilities, and rapid reaction forces. ${ }^{54}$ Unfortunately, as with Sandline, some of the company's business activities have courted controversy and undermined its claims to respectability. In April 2003, the British foreign secretary publicly accused the firm of jeopardizing the peace process in Ivory Coast by reportedly recruiting personnel to intervene in the fighting. ${ }^{55}$ Currently, the absence of competition in the military provider field means that any government seeking these services has few reliable options. It also remains to be seen whether many well-established PMCs would want to enter the high-risk business of direct combat, even if such a role were viewed as legitimate.

There are no reliable data on the likely costs of employing a PMC in a combat role, although claims have been made about the cost effectiveness of these enterprises based on the interventions of military provider firms in Africa. EO's fee for its operation in Sierra Leone is reported to have been $\$ 35$ million, which compared favorably with the $\$ 47$ million for the scheduled UN observer force at the time and the cost of the later UNAMSIL mission. ${ }^{56}$ However, the demand for private security personnel in Iraq has pushed up the revenues of PMCs and inflated employees' salaries to record levels, not least to cover insurance costs. ${ }^{57}$ Given the limited number of companies offering direct combat services, the dangerous nature of the work, and the level of military skills required, the employment of a competent PMC in a combat role would not be a cheap option, even if it were an expedient one.

Military provider firms and top-flight security companies hire from the same pool of elite soldiers. Such enterprises provide a source of employment for retired officers and soldiers, who often leave the armed services in the prime of life, with not only years of military experience, but also a profound understanding of the norms of mili-

51 See Barry Yeoman, "Need An Army? Just Pick Up the Phone," New York Times, 2 April 2004.

52 Jeremy Lovell, "Privatized Military Wave of the Future, Firms Say," Birmingham Post, 12 May 2003, 11.

53 Stephen Fidler and Thomas Catan, "Private Military Companies Pursue the Peace Dividend," The Financial Times, 24 July 2003.

54 See http://www.northbridgeservices.com/services_opsupport.htm.

55 British Government, Official Report, 1 April 2003; Vol. 402, c. 52WS.

56 Brendan O'Shea, "The Future of United Nations Peacekeeping," Peacekeeping and International Relations (April-September 2001): 17-18; and David Shearer, "Privatising Protection," World Today (August/September 2001).

57 See discussion in Isenberg, "Fistful of Contractors," 25-26. 
tary behavior. PMCs can provide a means by which the expertise of these military personnel can continue to be leveraged on behalf of a state, albeit at a price. But recruitment by PMCs could have a negative impact on retention and morale in national armed forces, especially if private-sector soldiers were to be deployed on a battlefield alongside regular troops performing the same tasks, but with lower pay and greater liabilities. The high salaries on offer in Iraq have already caused elite soldiers from armed forces on both sides of the Atlantic to retire prematurely in record numbers. ${ }^{58}$ The U.K. has even resorted to offering soldiers "sabbaticals" from the army to enable them to work for private security firms. ${ }^{59}$ While the situation in Iraq has resulted in a unique demand for private security operatives, which is unlikely to reoccur on a similar scale, a growth in the number of military provider companies could cause a hemorrhage of critical skills from leading Western militaries, as well as create the unacceptable situation where a government funds the training of special forces and other elite soldiers, only to end up having to buy back their services from the private sector.

Despite the good combat record of those few modern military provider companies to take the field, formed bodies of mercenaries have not always proved the most reliable of troops - hence Machiavelli's famous warning that, "Mercenaries and auxiliaries are useless and dangerous. If a prince bases the defense of his state on mercenaries he will never achieve stability or security." ${ }^{60}$ Even when integrated into a state's armed forces and subject to military law, it might be impossible to eliminate all the tensions between a commercial organization seeking to maximize profit and the security objectives of a contracting state. As reports of waste and over-billing from Iraq suggest, military establishments currently lack the institutionalized knowledge required to draw up, supervise, and administer complex contracts with private sector military firms, ${ }^{61}$ although it is often overlooked that most private firms have performed creditably in Iraq, and many PMC employees have died fulfilling their contracts. ${ }^{62}$

\section{Military Provider Companies and International Law}

International regulatory measures are largely concerned with prohibiting traditional mercenary activity, and are widely recognized as both impractical and ineffective when

58 David Rennie and Michael Smith, "Weary Special Forces Quit for Security Jobs," The Daily Telegraph, 31 March 2004; and Associated Press, "Many Elite Soldiers Leave for Better Pay," New York Times (web version), 21 July 2004.

59 Sean Rayment, "Soldiers Are to Be Allowed a Year off to go to Iraq," Daily Telegraph, 23 May 2004.

60 Niccolo Machiavelli, The Prince (London: Penguin, 1968), Chapter XII, 77.

61 See, for example, T. Christian Miller, "Pentagon Waste in Iraq May Total Millions, Investigators Say," Los Angeles Times, 16 June 2004.

62 "Hundreds" may have died, according to David Simons, "Occupation for Hire: Private Military Companies and their Role in Iraq," RUSI Journal 149:3 (June 2004): 71. 
applied to PMCs. ${ }^{63}$ Both Article 47 of the 1977 Additional Protocols to the Geneva Conventions and the 1989 UN International Convention Against the Recruitment, Use, Financing, and Training of Mercenaries focus on individuals recruited to fight in a specific conflict rather than the regular employees of an established company hired by a recognized government. ${ }^{64}$ Most legislation at the national level, where it exists, is also aimed at countering the recruitment or use of individual mercenaries. Only a few states have laws that apply to the private military industry, and these are of questionable effectiveness.

International law does not permit civilians to participate directly in hostilities. Civilians who do so may be classed as illegal combatants and treated as mercenaries, or possibly war criminals. ${ }^{65}$ The Geneva Conventions of 1949 and the Additional Protocols of 1977 included members of the armed forces and even guerrillas in their provisions but were, of course, drafted before the advent of modern private military enterprises. The legal position of PMCs on the battlefield remains ambiguous, although employees of military provider firms can be incorporated into the forces of a contracting state to acquire legitimacy as combatants. ${ }^{66}$ The French Foreign Legion, the U.K.'s Gurkhas, and the Swiss Guard at the Vatican are formed units of troops that serve foreign governments, but are not classed as mercenaries because they are sworn into the service of the relevant state, subject to military law, and are integrated into a recognized chain of command. A PMC could be similarly "nationalized" by a country seeking to create a specialized capability, such as an expeditionary force. ${ }^{67}$

63 See, for example, Gerry Cleaver, "Subcontracting Military Power: The Privatization of Security in Contemporary Sub-Saharan Africa," Crime, Law \& Social Change 33:1-2 (March 2000): 131-149.

64 Both documents define a "mercenary" narrowly and cumulatively using six criteria:

- Is specifically recruited locally or abroad in order to fight in an armed conflict;

- Takes a direct part in hostilities;

- Is motivated to take part in hostilities essentially by the desire for private gain and is promised by, or on behalf of, a party to the conflict material compensation substantially in excess of that promised or paid to combatants of similar ranks and functions in the armed forces of that party;

- Is neither a national of a party to the conflict nor a resident of territory controlled by a party to the conflict;

- Is not a member of the armed forces of a party to the conflict;

- Has not been sent by a state which is not a party to the conflict on official duty as a member of its armed forces.

65 The Guantanamo Military Commission has suggested that illegal participation in combat may be a war crime.

66

See the discussion in Michael J. Schmitt, "Humanitarian Law and Direct Participation in Hostilities by Private Contractors or Civilian Employees," Chicago Journal of International Law (forthcoming).

67 The term "nationalization" is used in a UN context by Christopher Spearin, International Peacekeeping, 36. The term "public PMC" has also been used to describe this development. 
A less comprehensive arrangement might allow employees of PMCs to be hired as voluntary, sponsored reserves of the armed forces, similar to the arrangements under the U.K.'s Reserve Forces Act in $1996 .{ }^{68}$ A related measure is also under consideration in the U.S. that would allow contracted security personnel to be given temporary commissions as reserve component officers in order to subordinate them to the military chain of command. ${ }^{69}$ When serving with the armed forces, contractors would be subject to service regulations and discipline to ensure that they conformed to the norms of military behavior and the laws of war. As the Geneva Conventions and the Statute of the International Criminal Court apply to individuals, PMC employees engaged in combat roles would be liable for prosecution for war crimes if they committed breaches of international humanitarian law. Incorporating contractors into a state's armed forces would also permit oversight and accountability, as well as ensuring that troops from a provider firm obeyed military commands.

In practice, military provider firms have already sought to acquire legal combatant status for their employees and avoid possible prosecution for mercenary activities by arranging for them to become provisional members of an employing government's security forces. Sandline's ill-fated contract with the government of Papua New Guinea in 1997 is a notable example. The company's personnel were sworn in as "special constables" in order to give them the authority to bear arms and conduct military operations. ${ }^{70}$ However, if EU governments were to seek to make regular use of military provider firms, a more permanent legal arrangement than the somewhat ad hoc Sandline solution would be required, especially to avoid bureaucratic problems that could delay the rapid deployment of a partially privatized intervention force.

\section{The Failure to Legitimize Military Provider Firms}

None of the practical or legal barriers to the employment of military provider firms is insurmountable. The real obstacle to the use of PMCs in direct combat is that such a role is not generally viewed as legitimate or appropriate for the private sector. While the use of PMCs in training, logistical, security, and other supporting roles is becoming more or less an accepted feature of the modern military environment, this is not true of military provider companies, which are still widely viewed as indistinguishable from mercenaries. ${ }^{71}$ As long as this is the case, major PMCs - anxious not to jeopardize

68 Krahmann, "Controlling Private Military Companies," 8-9.

69 Ronald W. Reagan National Defense Authorization Act for Fiscal Year 2005, S. 2400, 23 June 2004, Sect. 864, "Management Plan for Contractor Security Personnel," c. 1; available at: http://www.congress.org/congressorg/webreturn/?url=http://thomas.loc.gov/cgi-bin/query/ z?c108:S.2400.

70 P.W. Singer, Corporate Warriors, 193-94; see also the example cited at note 53.

71 Particularly strident opposition to military provider firms has come from Enrique Ballesteros, the former UN Special Rapporteur on the question of mercenaries. See UN Economic and Social Council, Commission on Human Rights, E/CN.4/2004/15, 24 December 2003; available at: http://daccessdds.un.org/doc/UNDOC/GEN/G03/173/13/PDF/G0317313.pdf?Open Element. 
lucrative government contracts to supply support services - are unlikely to offer direct combat as a part of their portfolios. Doug Brooks has acknowledged that the future of military provider firms largely depends on regulation of the industry. Without legitimacy, he claims that firms will be disinclined to invest in this area of the market because they remain vulnerable to changes in governments' policies with regard to extant international or domestic laws against mercenary activity.

It is not surprising that the message on Sandline's website cites "general lack of governmental support for Private Military Companies willing to help end armed conflicts in places like Africa..." as the reason for the firm's decision to cease trading. ${ }^{73}$ Those governments that have sought to regulate the growing private military sector have shown little sympathy for the aspirations of firms seeking a direct combat role. Currently the U.S. has the most progressive regulatory system for the private military sector. But U.S. doctrine specifically rules out the deliberate employment of private contractors in combat. ${ }^{74}$ The involvement of security firms in firefights in Iraq has already resulted in the reinforcement of existing regulations on the tasking and arming of private sector employees. Despite support in some quarters for the use of military provider firms in both a peacekeeping and enforcement role in Africa, ${ }^{75}$ there is no indication that the government would be willing to employ a PMC in a combat role alongside U.S. forces in the foreseeable future. ${ }^{76}$ In the 1990 s, members of the apartheid-era South African security forces found a ready market for their skills in PMCs operating in sub-Saharan Africa. Although the personnel employed by EO and Sandline proved both more effective and better behaved than most local state militaries, their links with the former apartheid regime alone were enough to generate controversy. South Africa's Regulation of Foreign Military Assistance Bill of 1997 introduced a control and li-

72 Doug Brooks, "Messiahs or Mercenaries: The Future of International Private Military Services," in Managing Armed Conflicts in the $21^{\text {st }}$ Century (London: Frank Cass, 2001), 13637.

73 See http://www.sandline.com/.

74 Joint Chiefs of Staff, Doctrine for Logistics Support of Joint Operations, Joint Publication 4-0, 6 April 2000, at V-1.

75 See Jim Fisher-Thompson, "Contracting for Peace is Rational Approach"; and "Important Role Seen for Private Firms in African Peacekeeping," 15 October 2004. Available at: http://usinfo.state.gov.

76 Subordinate Commanders in the U.S. Central Command (CENTCOM) area of operations have been reminded that General Order 1 A prohibits contractors from carrying weapons, except when an exception to policy is requested for personal protection or contracted security duties. To preserve contractors' non-combatant status, exceptions are not granted when the intention is to guard military personnel, military convoys, military supply routes and military facilities. Headquarters, Multi-National Corps-Iraq, Information Paper, "Procedures to Obtain CENTCOM Authority to Arm Government Contractor Employees," 29 July 2004 (on file with author). A discussion by the author with a senior Pentagon official on 15 November 2004 confirmed that the Department of Defense would continue to proscribe a direct combat role for PMCs employed by the U.S. government. 
censing regime that implicitly sought to curb the activities of firms that offered combat services. ${ }^{77}$

In Europe, the French have adopted a tough stance on PMCs, passing the Réppression De L'Activité De Mercenaire act of April 2003, which effectively bans military provider firms as well as individuals from direct participation in combat. ${ }^{78}$ EU member states Italy, Belgium, and Cyprus are among the countries to have signed and ratified the UN convention on mercenaries, although, as noted above, this measure is more applicable to individuals than companies. ${ }^{79}$ Uniquely, the U.K. has attempted to take the lead in addressing the recognition and possible wider employment of PMCs. A "Green Paper" discussion document on the options for regulation of the private military sector was released in February 2002. In the foreword to the document, Jack Straw, the Foreign Secretary, acknowledged that, "A strong and reputable private military sector might have a role in enabling the $\mathrm{UN}$ to respond more rapidly and effectively in crises." 80

The British government's "Green Paper" recognized that a regulatory regime could eliminate many of the concerns about accountability, lack of transparency, and illegality in the private military sector and offered licensing and registration options for both companies and their services. ${ }^{81}$ Nevertheless, attempts by the government to draw a distinction between the activities of responsible military provider companies and traditional mercenaries failed to convince the many government officials, parliamentarians, and journalists that continued to view such enterprises in a negative light. ${ }^{82}$ Most commentaries on the document rejected a direct combat role for PMCs. The House of Commons Select Committee on Foreign Affairs recommended, "private companies be expressly prohibited from direct participation in armed combat operations." NGO International Alert drew similar conclusions based on an arguably contentious interpretation of Article 47 to Protocol 1 of the Geneva Conventions of $1977 .{ }^{84}$ The official response from the Ministry of Defense was less uncompromising, but still ruled

77 Republic of South Africa, "Regulation of Foreign Military Assistance Bill," Ministry of Defense, No. 54, 1997, ISBN 0621272183.

78 Réppression De L'Activité De Mercenaire, April 2003. See discussion at: www.assembleenationale.fr/12/cra/2002-2003/185.asp.

79 Germany and Poland have signed but not ratified the Convention.

80 Foreign and Commonwealth Office, Private Military Companies: Options for Regulation, HC 577 (London: The Stationery Office, 12 February 2002), 4.

81 Ibid, 22-27.

82 See, for example, "Mad Mike Comes in From the Cold: Mercenaries," The Economist, 16 February 2002; and the editorial "It's Foolish to Rely on Mercenaries for Security," The Independent, 14 February 2002.

83 Ninth Report of the Foreign Affairs Committee, Private Military Companies, Session 20012002, Response of the Secretary of State for Foreign and Commonwealth Affairs, Cm. 5642, October 2002, 5, (k).

84 Chaloka Beyani and Damian Lilly, "Regulating Private Military Companies: Options for the UK Government," International Alert, August 2001. Available at: http://www.internationalalert.org/pdf/pubsec/reg_pmc.pdf. 
out a frontline role for the private sector in a U.K.-supported international operation. ${ }^{85}$ To date, the British government has taken no further formal action on the issue of PMCs.

Given the British influence in the EU on military matters, potential military provider firms may have hoped that a permissive regulatory regime in the U.K. might have prompted the consideration of similar measures in other member states. The drafters of the "Green Paper" and various commentators raised the possibility of cooperation within the EU to create an international regulatory regime based on a re-drafting of the current, flawed UN convention on mercenaries. ${ }^{86}$ EU legislation would certainly address common anxieties about weapons proliferation and human rights abuses, but given longstanding differences within Europe on security policy, a common EU approach appears a distant prospect. It would in any case be unlikely to offer any comfort to prospective military provider companies, given current attitudes towards them.

Spokesmen for combatant PMCs have stated a preference to work for legitimate governments, and have expressed a willingness to submit to the kind of regulatory regime necessary to bring respectability to their industry and distance themselves from the temporary "companies" set up to recruit traditional mercenaries. ${ }^{87}$ The IPOA code of conduct states that members "support effective legal and financial accountability to relevant authorities for their actions and the actions of company employees" and "pledge to work only for legitimate, recognized governments, international organizations, and non-governmental organizations." 88 Nonetheless, the private military sector has been unable to shed the mercenary tag. Nor have events in Iraq helped to legitimize PMCs in the eyes of the general public. References to mercenaries, reports of overcharging by military support firms, and concerns about a lack of accountability following the involvement of private sector employees in the prisoner abuse at Abu Ghraib have dominated media reports.

Outside of Iraq, the exploits of some colorful individual "mercenaries," widely reported in the press, continue to undermine the private military sector's aspirations to be classed as a respectable industry. ${ }^{89}$ Military provider firms in particular are in a "Catch-22" situation. Until they are viewed as wholly reputable, governments are re-

${ }^{85}$ Memorandum submitted by the Ministry of Defense to the House of Commons Select Committee on Foreign Affairs, House of Commons Defense Liaison Office, 27 May 2003.

${ }^{86}$ For example, the House of Commons Select Committee on Foreign Affairs recommended that services provided by PMCs be included in the EU Code of Conduct for Arms Exports legislation of 1998.

87 See, for example, "Private Military Companies-Independent or Regulated?" Sandline International, 28 March 1998.

89 Thomas Catan, "Mercenaries Seek a Change of Image," Financial Times Special Report: Defence Industry, 1 December 2004; Rory Carroll and Jamie Wilson, "Soldier of Fortune," Guardian Unlimited, 19 May 2004; and Robert Young Pelton, "Mercenary Hits It Big, Thanks to Iraq," Los Angeles Times, 24 June 2004. 
luctant to introduce a licensing and regulatory regime. However, it is exceedingly difficult for them to be accepted as legitimate without such regulation.

\section{Conclusion}

UN Secretary-General Kofi Annan once reportedly declared that the world was not yet ready for privatized peacekeeping. ${ }^{90}$ This is certainly true of the countries of so-called "post-modern Europe," which remain effectively "modern" in their approach to the state's monopoly over the legitimate use of violence. As Philip Bobbitt has argued, the evolution of warfare is intimately bound up with the growth and development of the modern nation state. ${ }^{91}$ Therefore, the rise of PMCs is a sensitive issue for governments, as it threatens to undermine their control of armed force, regarded as one of the foundations of state sovereignty. Advocates for the private military industry may claim that a private force can still be under state control and be accountable to it as a legitimate corporate enterprise. But such arguments will remain academic as long as fundamental reservations about the privatization of combat remain in the minds of policy makers and the public at large (although the cause of military provider firms would certainly be assisted if reputable PMCs were able to distance themselves successfully from comparisons with the seamier side of their industry).

As discussed earlier, the EU faces a gap between its security ambitions and the reality of its military capabilities. It remains to be seen whether initiatives to promote greater defense integration and role specialization will successfully enable EU member states to rise to the challenge of a global security role. PMCs are likely to play an increasingly important function in supplying support services for the expeditionary forces that will be critical to effective European power projection. While contracts for these firms will continue to rule out a direct combat role, the character of modern warfare suggests that their exclusion in practice will become progressively more difficult. Perhaps over time, particularly if EU regular armed forces prove unequal to the task, military provider companies may have the opportunity to demonstrate that they can play both a vital and legitimate role on the front line of EU intervention forces. Until then, the new condottieri will be unable to challenge the relevance of Machiavelli's warnings to the twenty-first century.

90 Cited in a number of sources, including Michele Griffin, "Blue Helmet Blues: Assessing the Trend Towards Subcontracting UN Peace Operations," Security Dialogue 30:1 (March 1999): 48.

91 Philip Bobbitt, The Shield of Achilles: War, Peace and the Course of History (London: Penguin Books, 2003). 


\section{Bibliography}

Barstow, David. "Security Firm Says Its Workers Were Lured Into Iraqi Ambush." New York Times (2004).

Beaver, Sarah. "The EU, a New Partner for the UN in Peacekeeping." RUSI Journal (2004): 149.

Beyani, Chaloka, and Damian Lilly. "Regulating Private Military Companies: Options for the UK Government." International Alert (2001).

Bobbitt, Philip. The Shield of Achilles: War, Peace and the Course of History. London: Penguin Books, 2003.

Brooks, Doug. "Hope for the Hopeless Continent: Mercenaries." Traders: Journal for the Southern African Region (2000).

Brooks, Doug. "Messiahs or Mercenaries: The Future of International Private Military Services." In Managing Armed Conflicts in the 21st Century , 136-137. London: Frank Cass, 2001.

Carroll, Rory, and Jamie Wilson. "Soldier of Fortune." Guardian Unlimited (2004).

Catan, Stephen Fidler and. "Private Military Companies Pursue the Peace Dividend." The Financial Times (2003).

Catan, Thomas. "Mercenaries Seek a Change of Image." Financial Times Special Report: Defence Industry (2004).

Cleaver, Gerry. "Subcontracting Military Power: The Privatization of Security in Contemporary Sub-Saharan Africa." Crime, Law \& Social Change 33 (2002): 1-2.

Cooper, Robert. "The New Liberal Imperialism." The Observer (2002).

Daruvalla, Abi. "Anatomy of a Massacre." Time (2002).

de Wijk, Rob. "European Military Reform for a Global Partnership." Washington Quarterly 27, no. 1 (2003): 197.

Giegerich, Bastain, and William Wallace. "Not Such a Soft Power: the External Deployment of European Forces." Survival 46, no. 2 (2004).

Griffin, Michele. "Blue Helmet Blues: Assessing the Trend Towards Subcontracting UN Peace Operations." Security Dialogue 30, no. 1 (1999): 48.

Isenberg, David. A Fistful of Contractors: The Case for a Pragmatic Assessment of Private Military Companies in Iraq. British American Security Information Council (BASIC), Research Report 2004-4 , 2004.

Lovell, Jeremy. "Privatized Military Wave of the Future, Firms Say." Birmingham Post (2003). 
Machiavelli, Niccolo. The Prince. London: Penguin, 1968.

Mawdsley, Jocelyn, and Gerrard Quille. "Equipping the Rapid Reaction Force: Options for and Constraints on a European Defence Equipment Strategy." Bonn International Center for Conversion 33 (2003).

McLaughlin, Abraham. "Guns for Hire Thrive in Africa." Christian Science Monitor (2004).

Mérand, Frédéric. "Dying for the Union?: Military Officers and the Creation of a European Defence Force." European Societies 5, no. 3 (2003).

Metz, Dr. Steven. Armed Conflict in the 21st Century, The Information Revolution and Post Modern Warfare . Carlisle, PA: Strategic Studies Institute, U.S. Army War College, 2000.

Michta, Andrew A.. "Central Europe and the Baltic Littoral in NATO." Foreign Policy Research Institute (2004).

O’Neil, Brendan. "Is it Mercenary to Join for Perks, Not War." Christian Science Monitor (2004).

O’Neill, Brendan. "A New Kind of Private War." Spiked-politics (2004).

O’Shea, Brendan. "The Future of United Nations Peacekeeping." Peacekeeping and International Relations (2001): 17-18.

Pelton, Robert Young. "Mercenary Hits It Big, Thanks to Iraq." Los Angeles Times (2004).

Priest, Dana, and Mary Pat Flaherty. "Under Fire, Security Firms Form an Alliance." Washington Post (2004).

Priest, See Dana. "Private Guards Repel Attack on U.S. Headquarters." Washington Post (2004).

Rayment, Sean. "Soldiers Are to Be Allowed a Year off to go to Iraq." Daily Telegraph (2004).

Rennie, David, and Michael Smith. "Weary Special Forces Quit for Security Jobs." The Daily Telegraph (2004).

Rubin, Elizabeth. "An Army of One's Own." Harper's Magazine (1997).

Shearer, David. "Private Armies and Military Intervention." Adelphi Paper No. 316 IISS (1998): 76.

Shearer, David. "Privatising Protection." World Today (2001).

Shishkin, Philip. "Growing Soft: How the Armies of Europe Let Their Guard DownGuaranteed Jobs for Soldiers Leave Little Room to Buy Equipment or Even TrainBattle of the Belgian Bands." Wall Street Journal (2003). 
Simons, David. "Occupation for Hire: Private Military Companies and their Role in Iraq." RUSI Journal 149, no. 3 (2004): 71.

Singer, P.W.. "Have Guns, Will Travel." New York Times (2003).

Singer, Peter W.. Corporate Warriors: The Rise of the Privatized Military Industry . Ithaca, NY: Cornell University Press, 2003.

Smith, Eugene B.. "The New Condottieri and US Policy: The Privatization of Conflict and Its Implications." Parameters 32, no. 3 (2003).

Smith, John. The Development of Response Forces in NATO and the EU and the Evolving NATO-EU Relationship. NATO Parliamentary Assembly, Committee Reports, 2004 Annual Session, 2004.

Spearin, Christopher. "Private Security Companies and Humanitarians: A Corporate Solution to Securing Humanitarian Spaces?"." International Peacekeeping 8, no. 1 (2003): 28.

T. Miller, Christian. "Pentagon Waste in Iraq May Total Millions, Investigators Say." Los Angeles Times (2004).

Wohl, Jonah Schulhofer. "Should We Privatize the Peacekeeping." Washington Post (2000).

Yeoman, See Barry. "Need An Army? Just Pick Up the Phone." New York Times (2004). 